\title{
Biochar for removal of dyes in contaminated water: an overview
}

\author{
Saravanan Praveen ${ }^{1}\left[\right.$ D Josephraj Jegan ${ }^{2} \cdot$ Thillainayagam Bhagavathi Pushpa $^{2} \cdot$ Ravindiran Gokulan $^{3}$. \\ Laura Bulgariu ${ }^{4}$
}

Received: 28 April 2021 / Accepted: 30 November 2021

(c) The Author(s) 2022

\begin{abstract}
In recent years, numerous investigations have explored the use of biochar for the removal of organic and inorganic pollutants in single component systems. Biochar is a carbonaceous material produced from waste biomass, mainly by thermochemical conversion methods. This material was used as a biosorbent in various removal processes of pollutants, and its efficiency was strongly influenced by the characteristics of the biomass feedstock. This review integrates the recent works of literature to understand the biosorption behaviour of dyes onto biochar-based biosorbents. The factors influencing the biosorption process and the mechanisms describing the biosorption behaviours of the biochar have been broadly reviewed. Furthermore, the biosorption models can be used to comprehend the competence of the biochar as biosorbent for dye removal techniques.
\end{abstract}

Saravanan Praveen

praveensarvan@gmail.com; praveen.s@cmrit.ac.in

1 Department of Civil Engineering, CMR Institute of Technology, Bengaluru 560037, Karnataka, India

2 Department of Civil Engineering, University College of Engineering, Ramanathapuram 623513, Tamil Nadu, India

3 Department of Civil Engineering, GMR Institute of Technology, Rajam, Srikakulam 532127, Andhra Pradesh, India

4 Department of Environmental Engineering and Management, "Cristofor Simionescu" Faculty of Chemical Engineering and Environmental Protection, Gheorghe Asachi Technical University of Iaşi, 700050 Iaşi, Romania 


\section{Graphical Abstract}
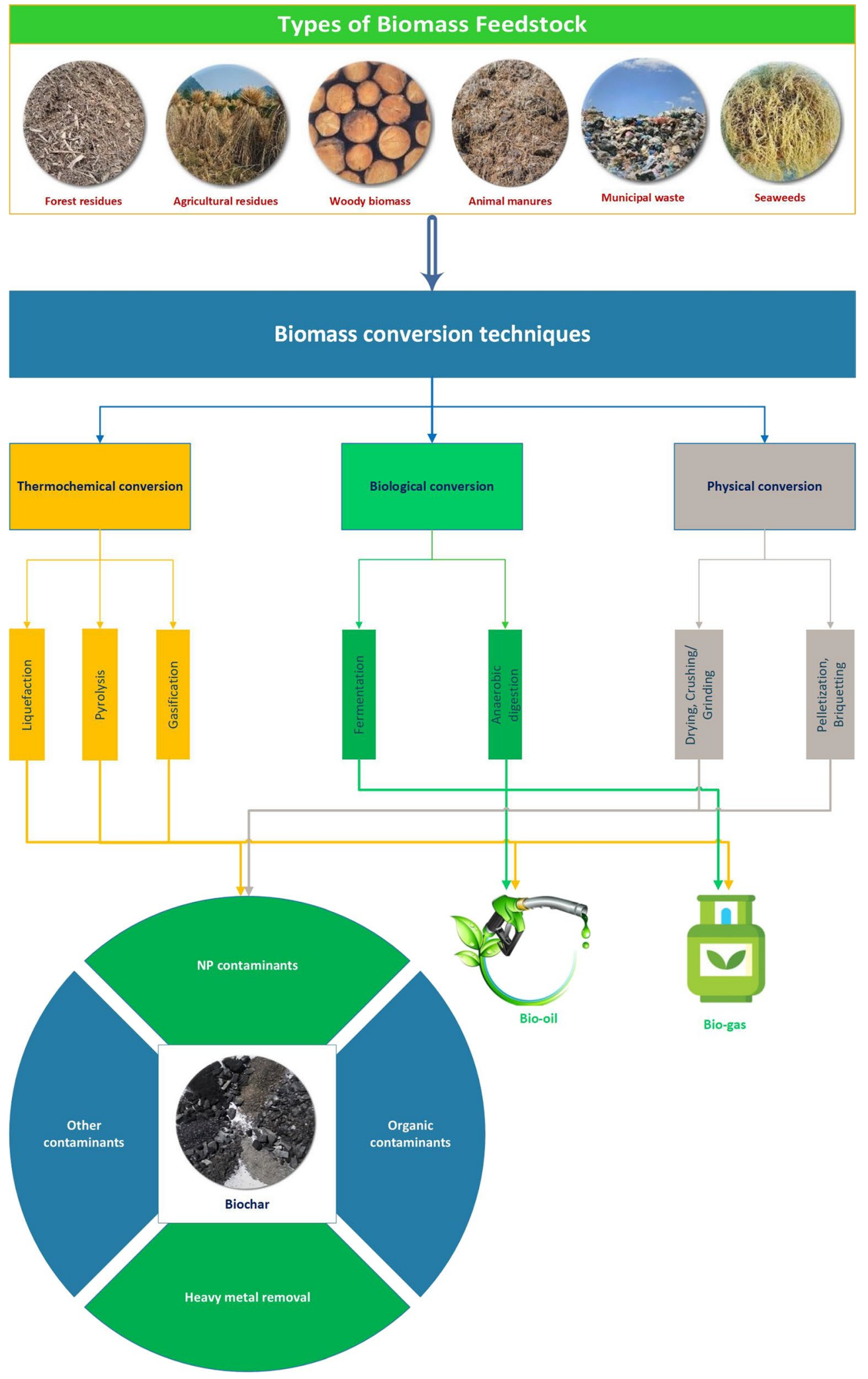

Keywords Biomass $\cdot$ Bioremediation $\cdot$ Biosorption $\cdot$ Biosorbent 


\section{Introduction}

The release of organic and inorganic pollutants into the environment can cause severe changes (contamination in the water, death of trees and grassland, more problems in wildlife, contamination in the food chain, negative health effects on the flora and fauna, severe human health problems etc.) in the atmosphere and generates various types of pollutions (Bhagavathi Pushpa et al. 2019). This is because these pollutants are toxic, mutagenic and carcinogenic, and their presence in ecosystems determines the decrease of the ecosystem quality (Farah et al. 2013). Most of the pollutants are produced by various domestic activities and industrial discharges. All living beings on the earth from microbes to whales depend upon the earth's water and air supply. When these resources are polluted, the survival of all forms of living things are directly threatened. In recent years, the term pollution has become a global concern. Over two-thirds of the earth is covered with water and increasing human population directly contributes to an increase in water pollution as a result of man-made activities (Bhagavathi Pushpa et al. 2016a).

In the current situation, the quality of water is a huge concern for humans (Schwarzenbach et al. 2010). The water is to be precious for the future generations, and it needs to be preserved, whereas the rate of contamination and depletion of natural resources is increasing day by day. The domestic activities have a direct or indirect impact on the quality of water. Subsequent impacts occur in the form of diminution of biodiversity, dangerous habitats, and an overall loss in the quality of natural life (Inyinbor et al. 2018).

Due to the impact of these pollutants on human health and the environment, it has become a global threat over the last decade (Thillainayagam et al. 2021). For example, the textile industry generates huge amounts of polluted aqueous effluents, due to the excessive water consumption for fabric processing (Priya et al. 2020). Other industries are also producing coloured and contaminated waters at the end of their technological processes (Pereira and Alves 2012). Polluted wastewater loaded with dyes has chemical stability, persistent colour and high Biochemical Oxygen Demand (BOD) and is intolerable for ecosystems (Wang et al. 2007). In India, the textile industry is the major sector that consumes huge amounts of dyes (Mathur et al. 2005). About 20\% of the world's total water pollution is due to such industrial dyeing activities (Streith 2018; Rita 2012) with an estimated amount of 2.8 Lakh tons of dyes per annum being released to the environment (Jin et al. 2007). Because of this, many countries have imposed strict laws and regulations for wastewater disposal and separate guidelines for each industry to reduce the discharge of pollutants into the environment.
Many industries have designed and implemented different treatment strategies to treat their effluents. For example, adsorption, ion-exchange, filtration, irradiation and coagulation, oxidation, Fenton's reagent $\left(\mathrm{H}_{2} \mathrm{O}_{2}-\mathrm{Fe}\right.$ salts), photochemical, ozonation, sodium hypochlorite $(\mathrm{NaOCl})$, and electrochemical destruction were used to remove the organic pollutants from the wastewater (Robinson et al. 2001; Yagub et al. 2014; Salleh et al. 2011).

Over the recent past, biological treatment has been one of the cost-effective technologies compared to other processes (Vijayaraghavan and Yun 2008a). Microorganisms were majorly used for the degradation of contaminants from the wastewater through different bioprocess techniques (Mcmullan et al. 2001). Biodegradation or biotic degradation is the biochemical degradation of contaminants by bacteria or other biological sources. These organisms are transforming pollutants through metabolic or enzymatic processes. Many bacteria species were successfully used for the biosorption of pollutants from effluents (Harshad Lade et al. 2015; Guadie et al. 2017; Neetha et al. 2018). Although the method is environmentally benign, high operating costs associated with long operating time hinder commercial process applications.

Biosorption is a technique that utilizes the biomass to adsorb contaminants from aqueous solutions. Compared to other conventional methods, biosorption is considered as one of the most effective treatment techniques, both techno centric and eco centric (Varshini and Das 2014; Bhagavathi et al. 2016b; Kucuker et al. 2017). Biobased sorbents (or biosorbents) such as fungi, bacteria, polysaccharide sorbents, algae (Sabah et al. 2016; Moghaz Reda and Abdo Sayeda 2018), and agricultural wastes (Vijayaraghavan and Yun 2008a) are cheap, available in large quantities, and their performances depend; the type of dye and the experimental conditions (including initial dye concentration, $\mathrm{pH}$, temperature, contact time, etc.). Therefore, biosorbents with a higher potential to bind/take dyes molecules are desirable (Macek and Mackova 2011).

These are the main reasons why recent environmental remediation studies have focused on the use of biochar and biochar-based adsorbents for the removal of contaminants from aqueous media (Tareq et al. 2019; Alam and Alessi 2019; Li et al. 2019). The characteristics of such materials highly depend on the nature of feedstock biomass, preparation conditions and the synthesis techniques. (Lee et al. 2018; Shakoor et al. 2019). All these factors strongly influenced the nature of superficial functional groups, surface charge, $\mathrm{pH}$, mineral content specific surface area and porosity of biochars (Tareq et al. 2019) and are responsible for their adsorptive performances. Resultant biochar plays a significant contribution to address the adsorbent requirements and globally, it was considered as an effective and low-cost 
treatment technique (Thines et al. 2017). Biochar from various feedstocks was made and effectively inspected for their sorption capacity towards various metals (Inyang et al. 2016) and nutrients (Kasak et al. 2018).

The main objective of this review is to provide a conceptual understanding of current research trends, discoveries and theories on biomass-derived biochar as an adsorbent for the removal of dyes from an aqueous solution. The key purpose of this study is to review the efficient use of biomass feedstocks for biochar synthesis, to investigate the dye sorption behaviour, and to review the effects of operational parameters on these adsorption processes.

\section{Biomass feedstock used for biochar preparation}

It is well known that the main source of feedstocks for the preparation of biochar is biomass. Biomass can be defined as animal or plant residue obtained from their transformations at the end of its utility (Irmak 2017). It covers wood and agricultural residues as lignocellulosic materials, and municipal solid waste and livestock residues, as non-lignocellulosic materials. These types of biomass can be directly converted into high value products, such as bioenergy, chemicals and materials by various thermochemical techniques. Depending on the value of the working temperature, pressure and time required for heating, thermochemical methods are classified into pyrolysis, gasification, liquefication and direct combustion. Of these methods, pyrolysis is considered the most cost-effective method, as it yields by-products, such as biochar, bio-oil and syngas, which have high economic value.

\subsection{Selection of biomass feedstock's categories}

The raw biomass that is considered as waste in agricultural practices, namely rice husk (Jegan et al. 2020a, b; Liu et al. 2012), coconut shell (Anton et al. 2017; Praveen et al. 2020), groundnut shell (Ahmad et al. 2012; Jegan et al. 2020b), wood wastes (Lucchini et al. 2013), sunflower seed husk (Saleh et al. 2016), cauliflower leaves, orange peels (Stella Mary et al. 2016), poplar wood (Suliman et al. 2015), raw fish scales (George et al. 2019), switch grass (Patrick et al. 2017), beech wood (Guizani et al. 2017), pinewood (Mohanty et al. 2013), timothy grass (Mohanty et al. 2013), soybean stover (Ahmad et al. 2012), saw dust (Liu et al. 2012), algae residues (Chang et al. 2015), seaweeds (Gokulan et al. 2019a, b, c; Kumar et al. 2021), walnut shell (Mukome et al. 2013), poultry manure (Kameyama et al. 2016), can be used efficiently for biochar production.

The composition and amounts of different constituents such as hemicellulose, cellulose and lignin vary depending on the type of feedstock materials used (Inyang et al. 2014). These constituents will undergo thermal decay during the pyrolysis process. This degradation of the constituents occurs first between 200 and $260{ }^{\circ} \mathrm{C}$ (hemicelluloses), $230-350{ }^{\circ} \mathrm{C}$ (cellulose) and lignin $\left(300-500{ }^{\circ} \mathrm{C}\right)$. Due to the seasonal availability of feedstocks biomass, it is preferable to use a combination of biomass feedstocks from different source points including agricultural residues, forestry wastes and manures, etc., to obtain biochar (Tong et al. 2011). Figure 1 illustrates the sustainability of biomass-derived by-products.

Different researches pointed out that the sorption of pollutants was based on several adsorption mechanisms and it depended on the type of feedstock that was used for biochar production. In general, the sorption capacity of the biochar was based on pore filling, electrostatic attraction, precipitation, complexation and ion exchange mechanism. For instance, Mohan et al. (2007) reported that the sorption capacity of the biochar obtained from agricultural waste and wood biomass is mainly due to the existence of superficial functional groups (such as: $\mathrm{C}=\mathrm{O}, \mathrm{C}-\mathrm{O},-\mathrm{OH}$, etc.), which can interact with inorganic or organic compounds from aqueous media. The sorption mechanism may vary depending on the characteristics of biochar and the physicochemical properties of the contaminants (Kumar et al. 2011; Gwenzi et al. 2017).

\subsection{Biochar development}

Thermochemical conversion methods such as pyrolysis, hydrothermal carbonization (HTC), and gasification are the most commonly used conversion techniques for biochar synthesis. The highest biochar yields were obtained in case of pyrolysis (Wang et al. 2019), and therefore this process was considered to be the most effective and economic in terms of biochar production (Waqas et al. 2020).

In pyrolysis, the biomass was heated to a temperature of $150-900{ }^{\circ} \mathrm{C}$ in an oxygen-free environment to convert biomass into biochar (Ahmad et al. 2014). During this thermal degradation, the organic compounds from the composition of biomass feedstock (hemicellulose, cellulose and lignin) are degraded. Thus, the yield of the pyrolysis products (bio-solid, bio-oil and biogas) also varies, depending on the temperature, retention time and heating rate, etc. As a function of these parameters, the pyrolysis processes are classified into slow, intermediate, fast and flash (Table 1). Figure 2 shows the classification of batch production process of biochar.

Slow pyrolysis can be defined as a continuous operation, where oxygen-free feedstock biomass is transferred to a furnace, on the other end, fast pyrolysis depends on very rapid heat transfer, usually to fine particles at less than $650{ }^{\circ} \mathrm{C}$ with a heating rate (ca $100-1000{ }^{\circ} \mathrm{C} / \mathrm{s}$ ). In the gasification 


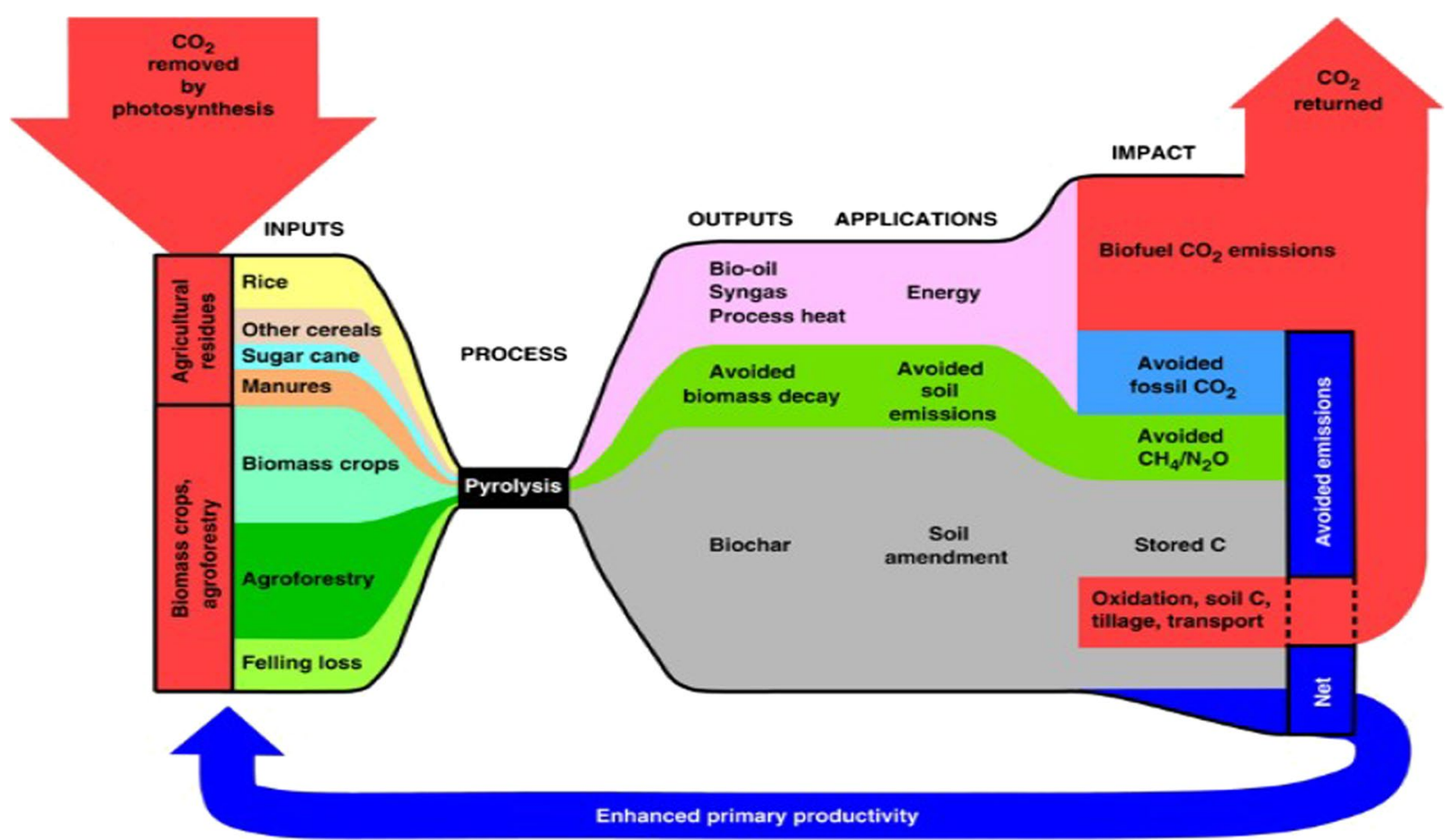

Fig. 1 Overview of the sustainability of biomass-derived biochar by pyrolysis. Reprinted from Woolf et al. (2010)

Table 1 Pyrolysis process conditions (Nartey and Zhao 2014)

\begin{tabular}{|c|c|c|c|c|}
\hline Process & Condition & Liquid (Bio-oil) & Solid (Biochar) & Gas (Syngas) \\
\hline Slow pyrolysis & Low-moderate temperature $\left(300-550{ }^{\circ} \mathrm{C}\right)$, long residence time & $30 \%$ & $35 \%$ & $35 \%$ \\
\hline Intermediate pyrolysis & $\begin{array}{l}\text { Low-moderate temperature }\left(450-550{ }^{\circ} \mathrm{C}\right) \text {, moderate hot vapour } \\
\text { residence time }\end{array}$ & $50 \%$ & $25 \%$ & $25 \%$ \\
\hline Fast pyrolysis & $\begin{array}{l}\text { Moderate temperature }\left(400-600{ }^{\circ} \mathrm{C}\right) \text {, short hot vapour residence } \\
\text { time }\end{array}$ & $75 \%$ & $12 \%$ & $13 \%$ \\
\hline Flash pyrolysis & High temperature $\left(750-1000{ }^{\circ} \mathrm{C}\right),(0.5 \mathrm{~s})$ & - & $50 \%$ & $50 \%$ \\
\hline Gasification & High temperature $\left(>700{ }^{\circ} \mathrm{C}\right)$, long vapour residence time & $5 \%$ & $10 \%$ & $85 \%$ \\
\hline Hydrothermal carbonization & $\begin{array}{l}\text { Elevated temperature }\left(<200^{\circ} \mathrm{C}\right) \text { elevated pressure, long resi- } \\
\text { dence time }(1-16 \mathrm{~h})\end{array}$ & - & $60 \%$ & - \\
\hline
\end{tabular}

chamber, the feedstocks are oxidised at the temperature of about $800{ }^{\circ} \mathrm{C}$ and high pressure (Oliver et al. 2013). In HTC, the conversion of biomass into biochar was carried out by the application of heat and pressure in the presence of water, reaction temperature $\left(160-800^{\circ} \mathrm{C}\right)$ and the reaction pressure must be maintained $(>1 \mathrm{~atm})$ in the liquid form (Vijayaraghavan 2019). This method is often applied to the wet biomass feedstock for biochar production. Slow pyrolysis and hydrothermal carbonization techniques are the most efficient thermochemical conversion methods to produce the biochar in terms of feedstocks and high carbon yield. However, the biochar derived from HTC technique was readily biodegradable, whereas biochar derived through slow pyrolysis technique was more stable and thus had a distinctly higher potential for carbon sequestration than HTC (Malghani et al. 2013).

\section{Biochar for bioremediation of dyes}

Biological techniques have been engaged commonly for the treatment of dyes from wastewaters. In recent years, these technologies have gained considerable attention and are currently in the process of commercialization (Vijayaraghavan and Yun 2008a). Biosorption is a process that utilizes inactive biological materials to sequester the concentration of pollutants from aqueous solutions. In recent years, biosorption is considered as a rapid, reversible, economic, 


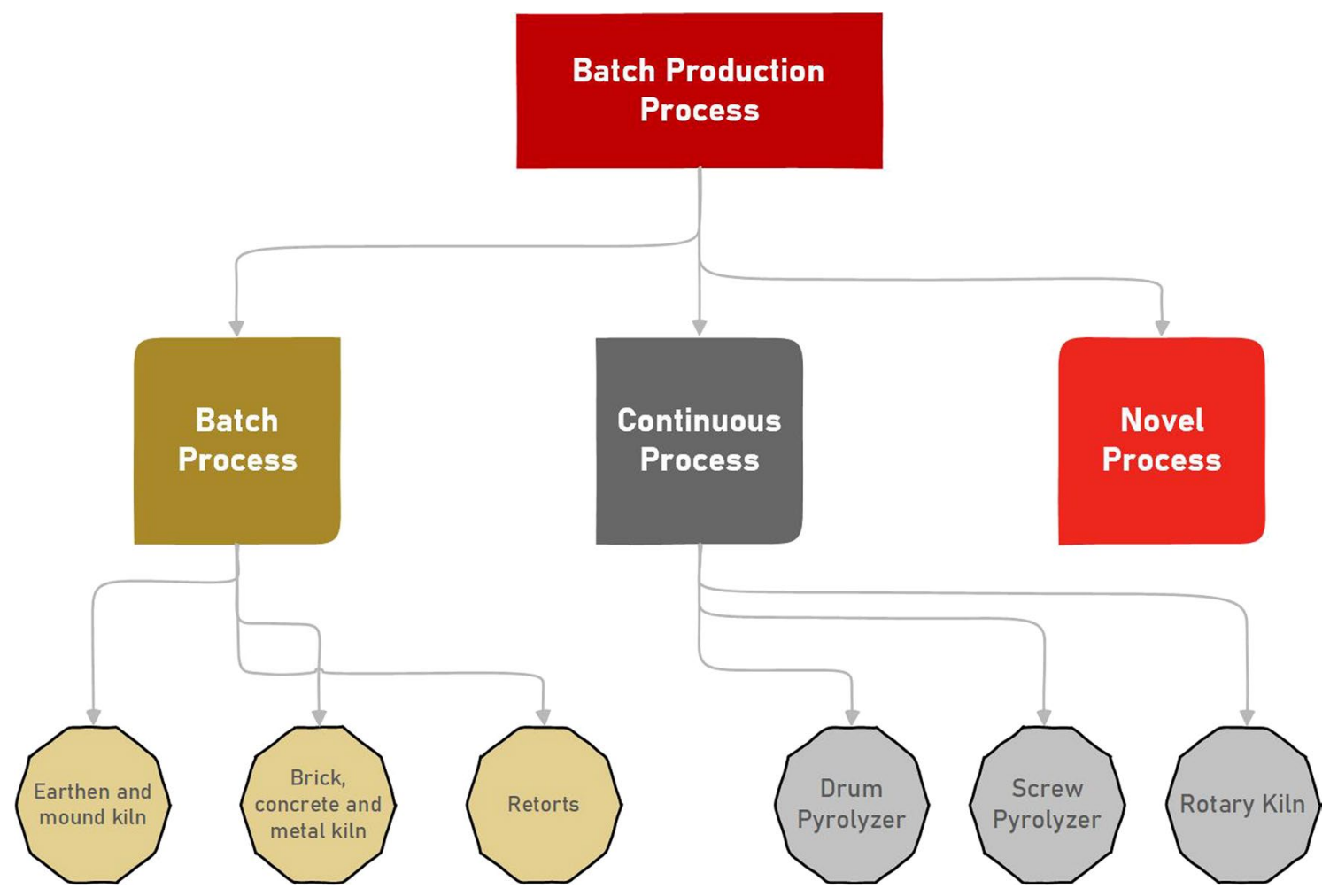

Fig. 2 Classification of the batch biochar production processes

and environment-friendly technology compared to conventional methods (Varshini and Das 2014; Kucuker et al. 2017). Biosorption is a promising potential alternative to conventional processes for the removal of dyes (Bhagavathi et al. 2016). The biobased sorbents used in the dye removal process are usually acquired from various industrial wastes, fungi, polysaccharide sorbents, bacteria, seaweeds, and agricultural wastes (Vijayaraghavan and Yun 2008a). The performance of biosorbents can vary within fairly wide limits, and mainly depends both on the nature of biomass and on the operating experimental conditions used during of biosorption (Vijayaraghavan and Yun 2008b). Therefore, finding an effective biosorbent to remove certain contaminants from aqueous media is still a major challenge.

An effective commercial biosorbent requires the following characteristics: high biosorption capacity (Wang et al. 2017), adequate surface characteristics (Shi et al. 2015), effective and low-cost separation of biosorbent from solutions (Xin et al. 2017; Rosales et al. 2017), resilient mechanical strength and thermal stability (Wang et al. 2017), availability and cost-effective preparation (Du et al. 2016; Saha et al. 2017). Thus, taking into account these requirements, biochar has been widely used for environmental bioremediation. Figure 3 exemplifies the heterogeneous structure of biochar and its potential applications in environmental bioremediation.
Today, many environmental remediation studies have focused on biochar and biochar-based adsorbents (Tareq et al. 2019). The operational use of biochar involves the study of the superficial properties of these materials, because these characteristics are important in the interactions with target contaminants, and their adsorptive performance, in order to find as many practical applications as possible (Novak 2018). Figure 4 demonstrates the potential pathways of biochar and its possible environmental applications.

\subsection{Factors affecting the biosorption of dyes on biochar}

Biochar's adsorption capacity is strongly influenced by the biochar characteristics and by several experimental parameters such as solution $\mathrm{pH}$, biochar dosage, temperature, initial dye concentration and contact time. In this section, the above-mentioned factors were discussed.

\subsubsection{Biochar characteristics}

The biochar produced from different conversion techniques has different functional compositions and characteristics, due to the variations in the operating conditions. Due to this variation, the biochar synthesis generally adopted the batch 


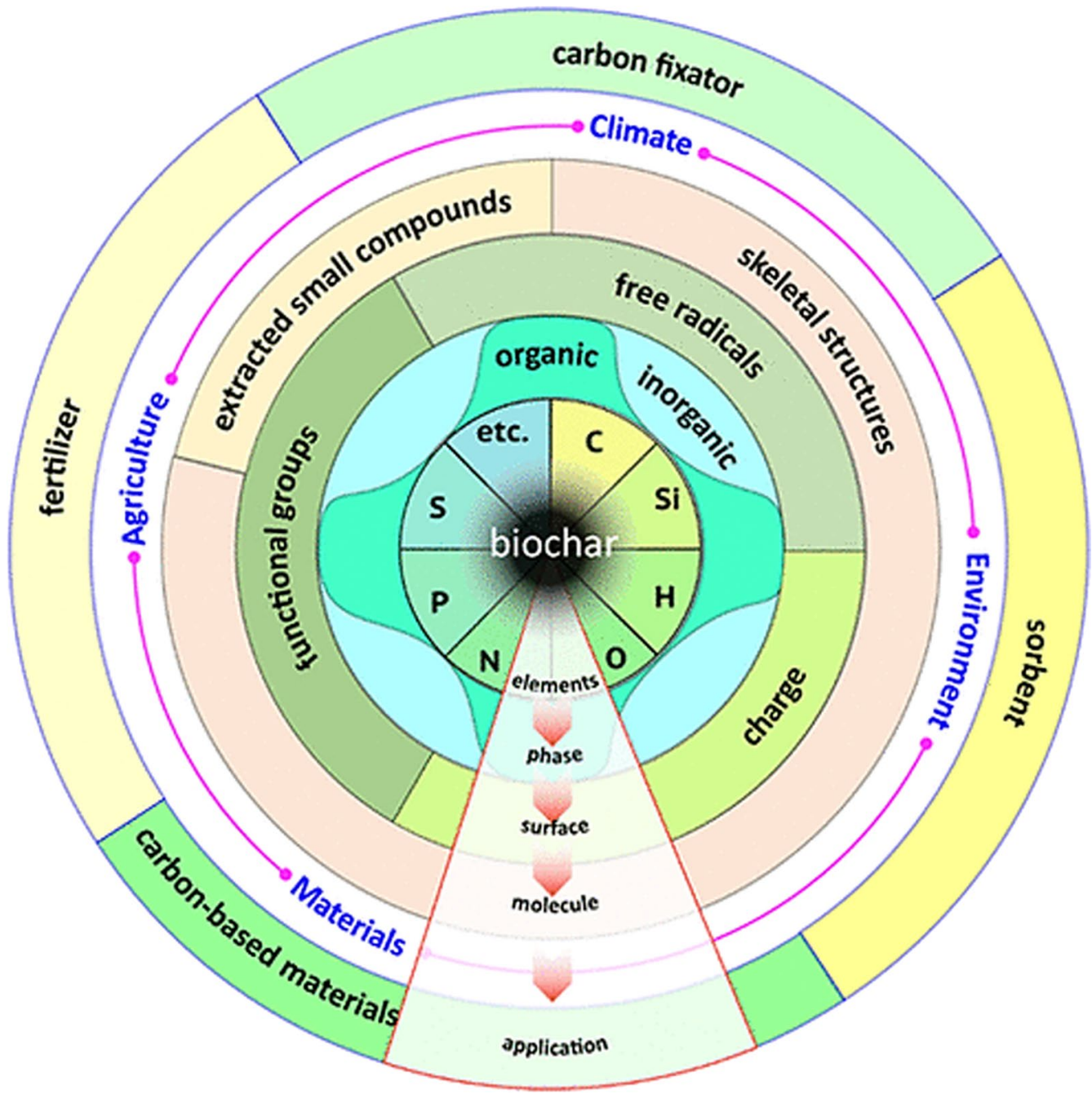

Fig. 3 Applications of biochar in environmental bioremediation. Reprinted (adapted) with permission from Xiao et al. (2018)

reactor mode. Thus, it is very important to understand the current research gap to attain the requirements of adsorptive tendency and uniform quality for large-scale productions. As mentioned earlier, the pyrolysis temperature, reactor residence time, the type of thermochemical conversion and nature of feedstock significantly influence the characteristics of the obtained biochar and have an important effect on the sorption performance of different pollutants.

During the pyrolysis process, the diameter of formed pores varies from nanometres to micrometres. Pore size is one of the most important factors governing the adsorption mechanism. Various researches have shown that the larger pore size is generated at high pyrolytic temperature and causes the surface area to increase. Along with the pyrolysis condition, the constituents of feedstock biomass also regulate the porosity. For instance, pyrolysis of lignin and cellulose enriched biomaterials produces microporous biochar. (Joseph et al. 2007).

The $\mathrm{pH}$ of the biochar also varies with pyrolysis temperature and feedstock material type. The $\mathrm{pH}$ of the biochar increases at high pyrolytic temperature (Jin et al. 2016) because higher pyrolytic temperature results in more ash content and degrades the acidic functional groups resulting in high $\mathrm{pH}$. The $\mathrm{pH}$ of the solution greatly affects the surface condition of the biochar. The presence of various functional elements at different proportions in the feedstock decreases the elemental ratio of the biochar at varying temperatures. The aromaticity and polarity of the specific biochar are due to these compositions. In general, high-temperature biochar provides a low $\mathrm{H} / \mathrm{C}$ and $\mathrm{O} / \mathrm{C}$ ratio compared to low-temperature biochar. The biochar's mineral content is also regulated by the feedstock kind and pyrolysis temperature, along with 


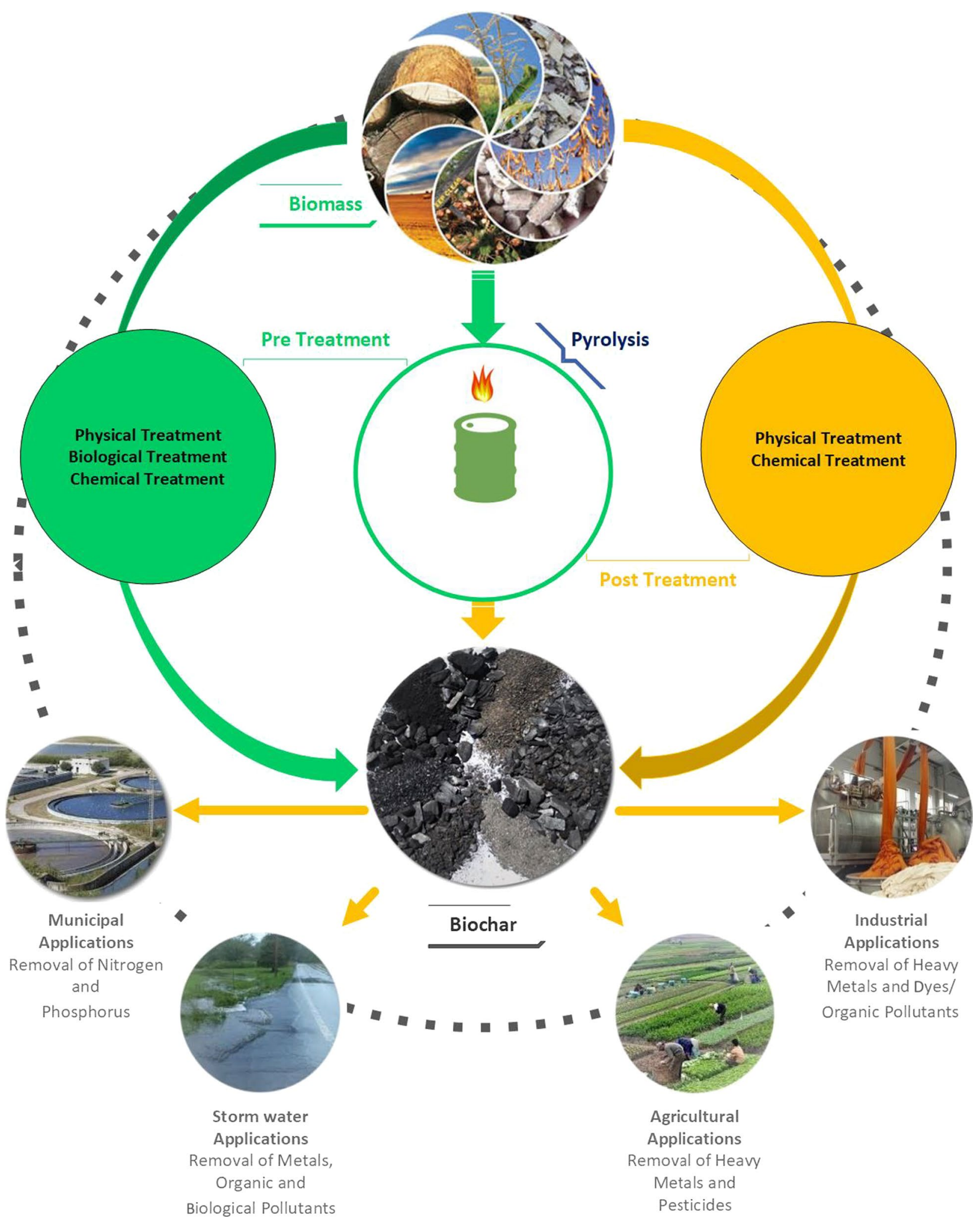

Fig. 4 Potential pathways of biochar and its possible environmental applications 
other physiochemical properties. The presence of mineral components in the biochar promotes precipitation and cationic exchange of pollutants from aqueous media (Uchimiya et al. 2010). Although these pollutants are removed by $\pi-\pi$ interaction, electrophilic interaction, hydrophobic action and hydrogen bonding are regulated by certain properties.

In brief, the nature of biomass feedstock and pyrolytic temperature will significantly influence the physiochemical properties of the synthesized biochar. The biochar which has a relatively high surface area, high hydrophobicity and microporosity obtained at high pyrolytic temperature will favour high sorption capacity for organic pollutants (Rajapaksha et al. 2014). Whereas the biochar obtained at low temperature has diminished pores and more oxygen-containing functional groups. On the other hand, the pyrolysis temperature will regulate the surface functions of biochar. For example, wood biomass-derived biochar has higher surface area than the biochar generated from industrial wastes and animal manure, even if all biochars are obtained under the same operating condition (Rajapaksha et al. 2014). Thus, by refining both parameters, the biochar properties make it more desirable for applications involved in the adsorption method. Table 2 illustrates the important characteristics of biochar required for the sorptive removal of organic pollutants (Table 3).

\subsubsection{Solution $\mathrm{pH}$}

The solution $\mathrm{pH}$ has a direct influence, not only on the adsorption capacity but also on the surface chemistry of the biochar as well as the accessibility of dye molecules for the binding sites (Vijayaraghavan and Ashokkumar 2019). From most of the previous studies, it is inferred that the optimum $\mathrm{pH}$ for dyes removal is often neutral or slightly alkaline (Sadhasivam et al. 2007). The percentage of dyes removal is maximum only at optimum conditions, and tends to decrease rapidly in acid or alkaline conditions. The solution $\mathrm{pH}$ is directly associated with the competition ability of hydrogen ions with adsorbate ions to active sites on the adsorbent surface (Janaki et al. 2012; Clifford and Noemi 2010).

Babaei et al. (2016) analysed the role of solution $\mathrm{pH}$ on the biosorptive removal of methylene blue dye by biochar derived from agricultural wastes. The inference was observed by varying the solution $\mathrm{pH}$ from 2 to 9 . The dye removal efficiency of the biochar was drastically improved, from 40 to $90 \%$, by the $\mathrm{pH}$ variation from 2 to 9 . The authors also pointed out the point of zero charge value (8.5). This upfront sorption behaviour of the biochar was attributed to the negative surface charge of the biochar, which favours electrostatic interactions, during of biosorption process.

Table 2 Adsorptive removal mechanisms of various organic pollutants by biochar in the aqueous medium

\begin{tabular}{llll}
\hline Pollutants & Biochar feedstock & Adsorption mechanisms & References \\
\hline $\begin{array}{l}\text { Brilliant blue } \\
\text { Basic red 09 }\end{array}$ & Rice and wheat straw & $\begin{array}{c}\text { Electrostatic attraction and intermolecular hydrogen } \\
\text { bonds }\end{array}$ & Qiu et al. (2009) \\
Trichloroethylene & Peanut & Hydrophobic action and hydrogen bonding & Ahmad et al. (2012) \\
Tetracycline & Rice husk & $\pi-\pi$ interaction & Liu et al. (2012) \\
Basic red 09 & Coconut shell & Electrostatic attraction & Praveen et al. (2020) \\
Basic blue 41 & Rice husk & Electrostatic interaction & Jegan et al. (2020b) \\
Basic violet 03 & Groundnut shell & Electrostatic attraction & Jegan et al. (2020a) \\
\hline
\end{tabular}

Table 3 Adsorption characteristics of various pollutants with biochar

\begin{tabular}{lllll}
\hline Feedstock & Pollutant & Applicable Isotherm model & $\begin{array}{l}\text { Applicable Kinetic References } \\
\text { model }\end{array}$ \\
\hline Groundnut shell biochar & Basic Blue 41 & Langmuir, Freundlich, Sips, Toth & PFO, PSO & Jegan et al. (2020) \\
Groundnut shell biochar & Basic Red 09 & Langmuir, Freundlich, Sips, Toth & PFO, PSO & Jegan et al. (2020) \\
Cocos nucifera shell biochar & Basic Blue 41 & Langmuir, Freundlich, Sips, Toth & PFO, PSO & Praveen et al. (2020) \\
Cocos nucifera shell biochar & Basic Red 09 & Langmuir, Freundlich, Sips, Toth & PFO, PSO & Praveen et al. (2020) \\
Switch grass biochar & Methylene Blue & Langmuir, Freundlich & PFO, PSO & Park et al. (2019) \\
Switch grass biochar & Orange G & Langmuir, Freundlich & PFO, PSO & Park et al. (2019) \\
Switch grass biochar & Congo Red & Langmuir, Freundlich & PFO, PSO & Park et al. (2019) \\
Bovine bone biochar & Basic Red 09 & Langmuir, Freundlich & PFO, PSO & Cortes et al. (2019) \\
Fish scale biochar & Basic Red 09 & Langmuir, Freundlich & PFO, PSO & Cortes et al. (2019) \\
Rice husk biochar & Basic Blue 41 & Langmuir, Freundlich, Sips, Toth & PFO, PSO & Praveen et al. (2020) \\
Rice husk biochar & Basic Red 09 & Langmuir, Freundlich, Sips, Toth & PFO, PSO & Praveen et al. (2020) \\
\hline
\end{tabular}




\subsubsection{Biochar dosage}

Many investigations have been concentrated on adsorbent dosage during dye sequestration techniques to find out an optimum minimum sorbent dose required for maximum removal (Chattoraj et al. 2016). The rate of dye removal percentage was found to be quick in the initial hours and then decelerated when the biochar dose increased (Dawood et al. 2017). This rapid rate of percentage removal of dye with adsorbent dosage could be attributed to the availability of the sorption sites on the surface of the adsorbent. Whereas in diminished dosage conditions the dye molecules are more easily accessible thus the efficiency of dye removal per unit weight of biochar is higher (Alene et al. 2014; Uddin et al. 2017).

\subsubsection{Temperature}

From the previous research, it is evident that the temperature has a significant influence on the equilibrium dye uptake. Hence the temperature will be a vital design parameter affecting the sorption capacity (Iftekhar 2018). Generally, temperature exhibits a strong impact on the adsorption capacity, and it is directly proportional to the rate of reaction (Wahab et al. 2017). The increase in temperature increases physio-sorption and the decrease in temperature will result in a lower rate of physio-sorption. Porous substances are better adsorbents as they promote adsorption through an increased surface area. The rate of dye removal increases with the increase in temperature up to a certain limit, after that, there is a limitation in the process.

Sathishkumar et al. (2007) recommended that the optimum removal was obtained at $35^{\circ} \mathrm{C}$ to $40^{\circ} \mathrm{C}$ and warranted that the adsorbent was capable of adsorbing the adsorbate at any particular temperature. The change in temperature with varying uptake capacity was referred to endothermic (absorbs heat) or exothermic (releases heat) process (Karimi et al. 2019; Ofomaja and Ho 2008).

\subsubsection{Initial dye concentration and contact time}

The initial dye concentration of sorbent strongly influences the efficacy of adsorption process. Bustard et al. (1998) showed increasing initial concentration of dyes provided a significant force to cover all mass transfer resistance between the aqueous and solid phases. Also, increasing the initial dye concentration increases the number of collisions between dye anions and sorbent. On the other hand, a decrease in decolourization capacity may occur due to the accumulation effect of the dye concentration to inadequate biomass concentration for the uptake of higher concentrations. The role of initial concentration on the percent of dye removal has a limited effect on the adsorption due to the unavailability of the required number of active surface sites on the biochar. Thus, the removal percent becomes saturated at a particular dye concentration (Abbas 2013). However, the ratio between the dye molecules and the surface sites is low and the removal percent of dye molecules is high at the lower concentrations. Thus, the sorption becomes independent.

\subsection{Adsorption isotherms}

The movement of pollutants in aqueous media and succeeding development of containment measures have led to the use of adsorption among other techniques (Shooto et al. 2016). To understand an adsorption process, it is much needed to know the equilibrium information and the effect of concentration. The quality of adsorbent is known by the amount of sorbate that can attract and retain in an immobilized media. The sorption uptake can be expressed in $\mathrm{mg} / \mathrm{g}$ (milligrams of dye adsorbed per gram of the sorbent) or $\mathrm{mmol} / \mathrm{g}$.

The evaluation of single sorbate sorption performance is best based on a complete single sorbate sorption isotherm curve resultant under the same environmental conditions. The adsorption isotherm is usually derived for dye uptake versus the dye concentration in the solution at equilibrium. In common, the uptake increases as concentration increases and at higher concentrations it will reach saturation, thus resulting in a concave-shaped curve. These isotherms can be modelled to validate the data using several empirical models. Isotherms models also play a vital role in the technology transfer from lab scale to industrial applications. Different models were used to describe the operation mechanisms, analyse experimental functions, predict and optimize processes. Quite a few models are available to define sorption isotherm data which include one single-parameter model, seven two-parameter models, five three-parameter models, four four-parameter models and one five-parameter model.

In general, the Langmuir (1916) adsorption isotherm has traditionally been used to describe the gas-solid phase adsorption. In its description, Langmuir stated that the physical force of attraction was the key function for binding the nature of the adsorbents to the dye molecules and he signified in his equation with an assumption that all surface sites had an equal attraction for the adsorbate. Further, it was prolonged to analytically describe equilibrium relations between the bulk liquid phase and solid phase (Davis et al. 2003). In general, the following assumptions for the Langmuir model are made such that all sorption sites are uniform, one sorbate molecule reacts with one active site, and there is no interaction between sorbed species. At least one of these conditions is implicitly not met in the case of biosorption. In this process, there is more than one type of functional groups contributing to the biosorption process, each of which has a different affinity for sorbing dye molecules (Schiewer and 
Volesky 1995). The Langmuir model is frequently used to fit batch biosorption data and in most cases, they successfully describe the equilibrium of dye biosorption (Yagub et al. 2014).

Originally, the Freundlich (1906) isotherm adsorption was empirical. But later, however, it was interpreted as sorption on heterogeneous surfaces or surface with supporting sites of different affinities (Schiewer and Volesky 1995; Davis et al. 2003). It was assumed that the stronger binding sites were first occupied and that the binding force decreased with the increasing occupancy of the site. Redlich and Peterson (1959) integrated the characteristics of both Langmuir and Freundlich models into a unified solution of adsorption with a hybrid mechanism and it doesn't have monolayer nature of adsorption (Gimbert et al. 2008).

Afshin et al. (2018) experimented the adsorptive removal of BB41 onto activated carbon derived from algae using batch equilibrium method. The isotherms were analysed using the two-parameter isotherm models and the Langmuir model was described as the best fit for the experimental datasets. Sivarajasekar and Baskar (2013) studied the basic red 9 adsorptions in batch mode using activated carbon as adsorbent derived from immature cotton seeds. The experimental equilibrium data were analysed using 24 different isotherm models including one single-parameter model, six two-parameter, eleven three-parameter models, five fourparameter models and one five-parameter model. Among the all the 24 isotherms models analysed, Fritz-Schlunder-V was obtained to be the good sign of the experimental data using non-linear regression analysis.

\subsection{Adsorption kinetics}

Like conventional sorption processes, biosorption inherently involves very rapid sorption reaction mechanisms (Vijayaraghavan and Yun 2008b). Many researchers used kinetic models including pseudo-first and second-order models to inspect the experimental data to examine the sorption mechanism and potential rate controlling steps such as mass transport and chemical reaction processes (McKay et al. 1999). Thus, the effect of contact time was the crucial factor to determine the adsorption kinetics. Hence, the kinetics of adsorption is the basis for determining the performance of a fixed bed or other flow-through systems (Qiu et al. 2009).

Lagergren (1898) presented a first-order rate equation to describe the kinetic process of adsorption of oxalic acid and malonic acid to charcoal from liquid to solid phase, which is believed to be the earliest model of adsorption rate based on adsorption capacity. To distinguish kinetic equations from solution concentration based on adsorption capacity, Lagergren's first-order rate equation has been called a pseudofirst-order model (Ho and McKay 1998a). Ho and Mckay (1995) described a kinetic adsorption process for divalent metal ions on peat (Ho and McKay 1998b) and the bonding between metal ions and functional groups on peat such as aldehydes, ketones, acids and phenolic is responsible for the peat's cation exchange capacity (Ho and McKay 2000). As well, the pseudo-second-order equation was also called as Ho's second-order rate. This equation has been successfully applied to the biosorption kinetics of various dyes such as the removal of methylene blue from aqueous solution using coco-peat (Premkumar and Vijayaraghavan 2015) and sorption of Remazol dyes by green seaweed-derived biochar (Gokulan et al. 2019a).

\subsection{Adsorption mechanisms}

Conventional techniques are generally deployed to treat the wastewaters whereas in certain cases, different techniques are also deployed to treat wastewater, all of which are timeconsuming and expensive, resulting in reduced efficiency. Currently, biochar applications onto bioremediation have attracted the global research interest due to its eco-friendly, cost effective, and sustainable behaviour (Thompson et al. 2016). To confirm this unique characteristic of biochar for biosorption of various pollutants it becomes essential to understand the surface structural interactions and mechanisms. General biosorption mechanisms involved in the adsorption of organic pollutants are pore diffusion, hydrophobic action, hydrogen bonding, cationic and anionic interactions and partitioning through uncarbonized areas as demonstrated in Fig. 5.

In general, biochar synthesised at high pyrolysis condition has more surface area, aromatic nature with less polarity and acidic nature. In this condition, the hydrophobic adsorption takes place with the loss of oxygen and hydrogen-containing surface functional groups. The biochar formed at low temperatures has more functional groups and is vulnerable to the adsorption of polar organic groups by hydrogen bonding. The electrostatic force of action is the key mechanism in the adsorption process to extract the cationic dyes. Biochar derived from agricultural crop residues, peanut hull effectively removed cationic dyes like methyl violet, methylene blue, basic blue, crystal violet and rhodamine by using the electrostatic force of interaction as adsorption mechanism (Jegan et al. 2020a, 2020b; Praveen et al. 2020). Biochar produced at lower temperatures comprises of $\pi$-systems with functional groups consisting of retreating electrons and they are in deficient of electrons, so they can act as acceptors and interact with the electron-donating functional groups in the dye molecules. Whereas biochar produced at higher pyrolytic temperature contains both donors and retreater electrons and thus it can interact with both functions (Sun et al. 2012). However, the nature and type of reactions occurring between the dye molecules and sorbent surfaces are strongly impelled by the $\mathrm{pH}$. In high basic $\mathrm{pH}$ condition, 


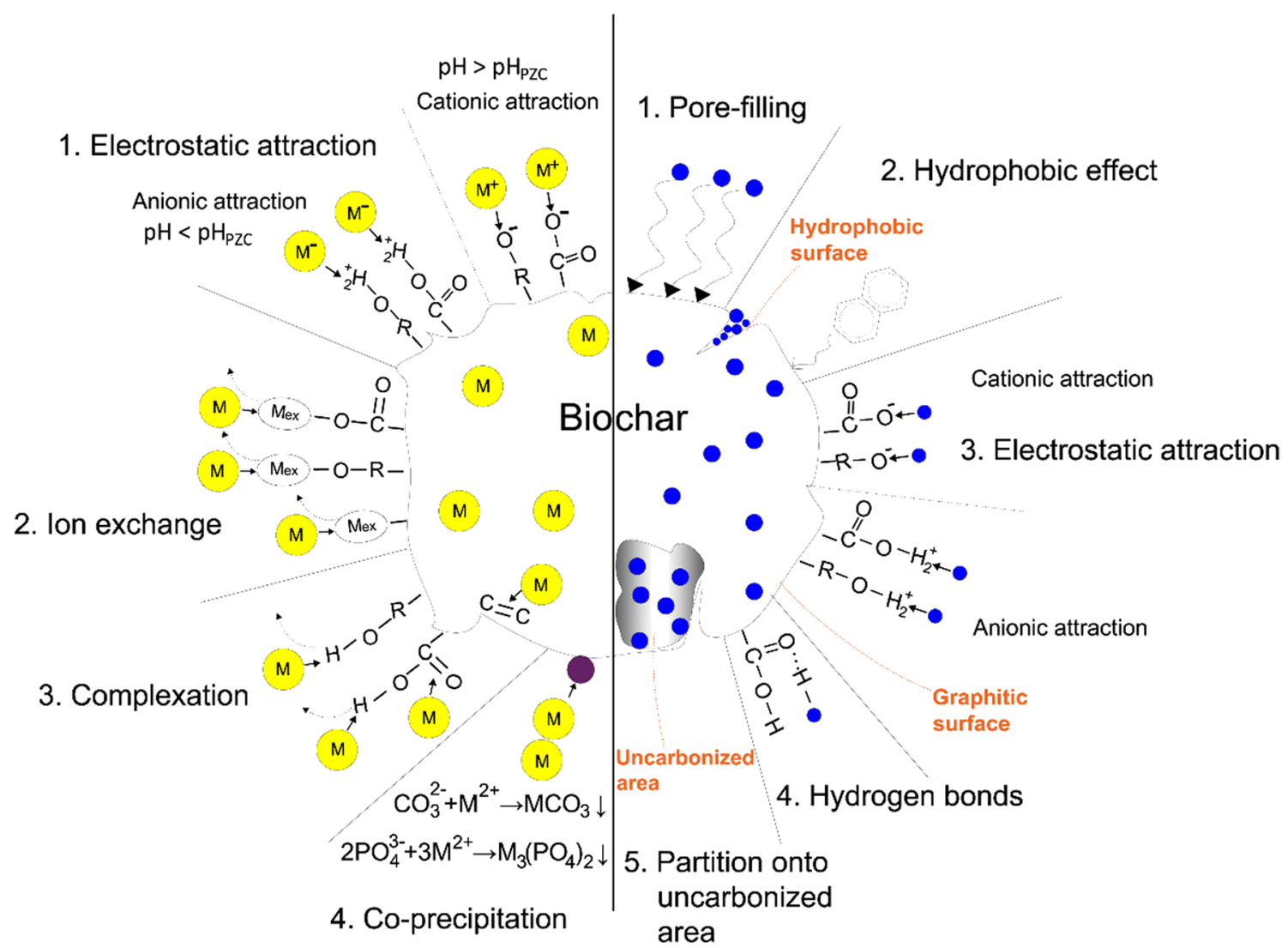

Heavy metals

Organic contaminants

- Organic contaminants

M Metal ions

Mineral components $\left(\mathrm{CO}_{3}^{2-}, \mathrm{PO}_{4}^{3-}\right)$

Mex Exchangeable metal ions

Fig. 5 Adsorption mechanisms of inorganic and organic contaminants. Reprinted from Wang et al. (2020)

the $\mathrm{OH}$ (phenolic) groups of adsorbent surfaces undergo alienation which leads to the negative surface charge of the adsorbent and thus it improves electrostatic reactions with cationic dye molecules whereas, in acidic condition, electron-donor-acceptor action surges and endorses hydrogen bonding with the dye molecules ( $\mathrm{Li}$ et al. 2016).

\section{Conclusion}

The review provides an overview of recent advancements in biochar production from various biomass, and its potential applications as biosorbent for biosorption of dyes. Literature review on the synthesis of biochar showed that many biological materials were used as feedstock for biomass and pyrolyzed through various processes to combat water contamination. Pyrolytic temperature, reactor residence time, heating rate, pyrolysis technique and feedstock natures have highly affected the properties and characteristics of the resultant biochar. The findings of the characterisation studies revealed that biochar can be used as an effective adsorbent. Insights from various studies suggest that the dyes are adsorbed by different processes including hydrogen affinity, electrostatic attraction, pore filling, hydrophobic and $\pi-\pi$ interaction. The previous investigations have indicated that biochar is feasible and novel because of its adsorption capacity, its eco-friendly nature and economic benefits. Despite the substantial usage of biochar as adsorbents, there are still uncertainties in the know-how of technology and more relevant researches are required in future work to close these uncertainties. 
Acknowledgements The authors would like to thank the anonymous reviewers for their comments.

Author contributions All authors have contributed equally to the work. The author read and approved the final manuscript.

Funding Not applicable.

Availability of data and materials Not applicable.

\section{Declarations}

Conflict of interest The authors declare that they have no conflict of interest.

\section{Ethics approval and consent to participate Not applicable.}

Consent for publication Not applicable.

Open Access This article is licensed under a Creative Commons Attribution 4.0 International License, which permits use, sharing, adaptation, distribution and reproduction in any medium or format, as long as you give appropriate credit to the original author(s) and the source, provide a link to the Creative Commons licence, and indicate if changes were made. The images or other third party material in this article are included in the article's Creative Commons licence, unless indicated otherwise in a credit line to the material. If material is not included in the article's Creative Commons licence and your intended use is not permitted by statutory regulation or exceeds the permitted use, you will need to obtain permission directly from the copyright holder. To view a copy of this licence, visit http://creativecommons.org/licenses/by/4.0/.

\section{References}

Abbas FS (2013) Dyes removal from wastewater using agricultural waste. Adv Environ Biol 7(6):1019-1026

Achieng GO, Kowenje CO, Lalah JO, Ojwach SO (2020) Preparation, characterization of fish scales biochar and their applications in the removal of anionic indigo carmine dye from aqueous solutions. Water Sci Technol. https://doi.org/10.2166/wst.2020.040

Afshin S, Mokhtari A, Vosoughi M, Sadeghi H, Rashtbari Y (2018) Data of adsorption of Basic Blue 41 dye from aqueous solutions by activated carbon prepared from filamentous algae. Data Brief. https://doi.org/10.1016/j.dib.2018.10.023

Ahmad M, Lee SS, Dou X, Mohan D, Sung JK, Yang JE et al (2012) Effects of pyrolysis temperature on soybean stover- and peanut shell-derived biochar properties and TCE adsorption in water. Bioresour Technol 118:536-544

Ahmad M, Rajapaksha AU, Lim JE, Zhang M, Bolan N, Mohan D, Vithanage M, Lee SS, Ok YS (2014) Biochar as a sorbent for contaminant management in soil and water: a review. Chemosphere 99:19-33

Alam MS, Alessi DS (2019) Modeling the Surface Chemistry of Biochars, Biochar from Biomass and Waste, pp. 59-72.

Alene AN, Abate GY, Habte AT (2020) Bioadsorption of basic blue dye from aqueous solution onto raw and modified waste ash as economical alternative bioadsorbent. J Chem. https://doi.org/10. 1155/2020/8746035

Babaei AA, Alavi SN, Akbarifar M, Ahmadi K, Esfahani AR, Kakavandi B (2016) Experimental and modelling study on adsorption of cationic methylene blue dye onto mesoporous biochars prepared from agrowaste. Desalin Water Treat. https://doi.org/ 10.1080/19443994.2016.1163736

Badr SA, Ashmawy AA, El-Sherif IY, Moghazy RM (2016) Non-conventional low-cost biosorbents for adsorption and desorption of heavy metals. Res J Pharm Biol Chem Sci 7(4):3110-3122

Bhagavathi Pushpa T, Jegan J, Praveen S (2016a) Utilization of biomass in environs - a review. Int J Adv Interdiscip Res 3(7):21-26

Bhagavathi Pushpa T, Vijayaraghavan J, Vijayaraghavan K, Jegan J (2016b) Utilization of effective microorganisms based water hyacinth compost as biosorbent for the removal of basic dyes. Desalin Water Treat 57(51):24368-24377

Bhagavathi Pushpa T, Jegan J, Praveen S, Gokulan R (2019) Biodecolorization of basic blue 41 using EM based composts: isotherm and kinetics. Chem Select 4(34):10006-10012. https://doi.org/ 10.1002/slct.201901774

Brassard P, Godbout S, Raghavan V, Palacios JH, Grenier M, Zegan D (2017) The production of engineered biochars in a vertical auger pyrolysis reactor for carbon sequestration. Energies 10(3):288

Bustard M, McMallan G, McHale AP (1998) Biosorption of textile dyes by biomass derived from Kluveromyces marxianus IMB3. Bioprocess Eng 19:427-430

Chang Y-M, Tsai W-T, Li M-H (2015) Chemical characterization of char derived from slow pyrolysis of microalgal residue. J Anal Appl Pyrolysis 111:88-93

Chattoraj S, Mondal NK, Sadhukhan B et al (2016) Optimization of adsorption parameters for removal of carbaryl insecticide using neem bark dust by response surface methodology. Water Conserv Sci Eng 1:127-141. https://doi.org/10.1007/s41101-016-0008-9

Clifford RL, Noemi MS (2010) Biological and abiotic color reduction of paper mill effluents during anaerobic composting. J Environ Eng 136(7):701-708

Cortes LN, Druzian SP, Streit AFM, Godinho M, Perondi D, Collazzo GC, Oliveira MLS, Cadaval TRS, Dotto GL (2019) Biochars from animal wastes as alternative materials to treat colored effluents containing Basic Red 9. J Environ Chem Eng. https://doi. org/10.1016/j.jece.2019.103446

Davis TA, Volesky B, Mucci A (2003) A review of the biochemistry of heavy metal biosorption by brown algae. Water Res 37:4311-4330

Dawood S, Sen TK, Phan C (2017) Synthesis and characterization of slow pyrolysis pine cone bio-char in the removal of organic and inorganic pollutants from aqueous solution by adsorption: kinetic, equilibrium, mechanism and thermodynamic. Biores Technol 246:76-81

Du Z, Zheng T, Wang P, Hao L, Wang Y (2016) Fast microwaveassisted preparation of a low-cost and recyclable carboxyl modified lignocellulose-biomass jute fiber for enhanced heavy metal removal from water. Biores Technol 201:41-49

Farah JY, El-Gendy NS (2013) Performance, kinetics and equilibrium in biosorption of anionic dye Acid Red 14 by the waste biomass of Saccharomyces cerevisiae as a low-cost biosorbent. Turkish J Eng Environ Sci. https://doi.org/10.3906/muh-1204-8

Freundlich HMF (1906) Over the adsorption in solution. J Phys Chem 57:385-471

Gimbert F, Morin-Crini N, Renault F, Badot PM, Crini G (2008) Adsorption isotherm models for dye removal by cationized starchbased material in a single component system: error analysis. J Hazard Mater 157:34-46

Gokulan R, Ganesh Prabhu G, Jegan J (2019a) A novel sorbent Ulva lactuca-derived biochar for remediation Remazol brilliant orange 3R in packed column. Water Environ Res 91(7):642-649

Gokulan R, Avinash A, Prabhu GG, Jegan J (2019b) Remediation of remazol dyes by biochar derived from Caulerpa Scalpelliformis - an eco-friendly approach. J Environ Chem Eng 7(5):103297. https://doi.org/10.1016/j.jece.2019.103297 
Gokulan R, Ganesh Prabhu G, Jegan J (2019c) Remediation of complex remazol effluent using biochar derived from green seaweed biomass. Int J Phytorem 21(12):1179-1189

Gokulan R, Vijayakumar A, Rajeshkumar V, Praveen S (2020a) Remazol effluent treatment in batch and packed bed column using biochar derived from marine seaweeds. Nat Environ Pollut Technol 19(5):1931-1936. https://doi.org/10.46488/NEPT.2020.v19i05. 017

Gokulan R, Ganesh Prabhu G, Avinash A, Jegan J (2020) Experimental and chemometric analysis of bioremediation of remazol dyes using biochar derived from green seaweeds. Desalin Water Treat 184:340-353

Guadie A, Tizazu S, Melese M, Guo W, Ngo HH, Xia S (2017) Biodecolorization of textile azo dye using Bacillus sp. strain $\mathrm{CH} 12$ isolated from alkaline lake. Biotechnol Rep 15:92-100

Guizani C, Jeguirim M, Valin S, Limousy L, Salvador S (2017) Biomass chars: the effects of pyrolysis conditions on their morphology, structure, chemical properties and reactivity. Energies 10(6):796

Gwenzi W, Chaukura N, Noubactep C, Mukome FND (2017) Biocharbased water treatment systems as a potential low-cost and sustainable technology for clean water provision. J Environ Manag 197:732-749. https://doi.org/10.1016/j.jenvman.2017.03.087

Ho YS, McKay G (1998a) A comparison of chemisorption kinetic models applied to pollutant removal on various sorbents. Process Saf Environ Prot 76(4):332-340

Ho YS, McKay G (1998b) Sorption of dye from aqueous solution by peat. Chem Eng J 70(2):115-124

Ho YS, McKay G (1998c) Sorption of dye from aqueous solution by peat. Chem Eng J 70(2):115-124

Ho YS, Ng JCY, McKay G (2000) Kinetics of pollutant sorption by biosorbents: review. Sep Purif Methods 29:189-232

Iftekhar S, Ramasamy DL, Srivastava V, Asif MB, Sillanpää M (2018) Understanding the factors affecting the adsorption of Lanthanum using different adsorbents: a critical review. Chemosphere. https://doi.org/10.1016/j.chemosphere.2018.04.053

Inyang MI, Gao B, Yao Y, Xue Y, Zimmerman A, Mosa A, Cao X (2016) A review of biochar as a low-cost adsorbent for aqueous heavy metal removal. Crit Rev Environ Sci Technol 46(4):406-433

Inyang M, Gao B, Zimmerman A, Zhou Y, Cao X (2014) Sorption and co sorption of lead and sulfapyridine on carbon nanotubemodified biochars. Environ Sci Pollut Res 1-9

Inyinbor Adejumoke A, Adebesin Babatunde O, Oluyori Abimbola $P$ et al (2018) Water pollution: effects, prevention, and climatic impact. In: Water Challenges of an Urbanizing World

Irawan A (2017) AIP Conference Proceedings-effect of torrefaction process on the coconut shell energy content for solid fuel. https:// doi.org/10.1063/1.4979226

Irmak S (2017) Biomass as raw material for production of high-value products, Biomass Volume Estimation and Valorization for Energy, Jaya Shankar Tumuluru, IntechOpen, https://doi.org/ $10.5772 / 65507$

Janaki V, Oh BT, Vijayaraghavan K, Kim JW, Lee KJ, Ramasamy AK, Kannan SK (2012) Application of bacterial extracellular polysaccharides/polyaniline composite for the treatment of remazol effluent. Carbohyd Polym 88:1002-1010

Jegan J, Praveen S, Bhagavathi Pushpa T, Gokulan R (2020a) Sorption Kinetics and Isotherm studies of Cationic dyes by Arachis hypogaea shell derived biochar as Low-cost adsorbent. Appl Ecol Environ Res 18(1):1925-1939. https://doi.org/10.15666/ aeer/1801_19251939

Jegan J, Praveen S, Bhagavathi Pushpa T, Gokulan R (2020b) Biodecolorization of Basic Violet 03 using biochar derived from agricultural wastes: isotherm and Kinetics. J Biobased Mater Bioenergy 14(03):316-326. https://doi.org/10.1166/jbmb.2020.1969
Jin XC, Liu GQ, Xu ZH, Tao WY (2007) Decolorization of a dye industry effluent by Aspergillus fumigatus XC6. Appl Microbiol Biotechnol 74:239-243

Jin J, Kang M, Sun K, Pan Z, Wu F, Xing B (2016) Properties of biochar-amended soils and their sorption of imidacloprid, isoproturon, and atrazine. Sci Total Environ 550:504-513. https:// doi.org/10.1016/j.scitotenv.2016.01.117

Joseph SD, Downie A, Crosky A, Lehmann J, Munroe P (2007) Biochar for carbon sequestration, reduction of greenhouse gas emissions and enhancement of soil fertility; a review of the materials science. Rend Circ Mat Palermo Suppl 48:101-106

Kameyama K, Miyamoto T, Iwata Y et al (2016) Influences of feedstock and pyrolysis temperature on the nitrate adsorption of biochar. Soil Sci Plant Nutr 62:180-184

Karimi S, Tavakkoli Yaraki M, Karri RR (2019) A comprehensive review of the adsorption mechanisms and factors influencing the adsorption process from the perspective of bioethanol dehydration. Renew Sustain Energy Rev 107:535-553. https://doi.org/ 10.1016/j.rser.2019.03.025

Kasak K, Truu J, Ostonen I, Sarjas J, Oopkaup K, Paiste P, Truu M (2018) Biochar enhances plant growth and nutrient removal in horizontal subsurface flow constructed wetlands. Sci Total Environ 639:67-74

Kucuker MA, Wieczorek N, Kuchta K, Copty NK (2017) Biosorption of neodymium on Chlorella vulgaris in aqueous solution obtained from hard disk drive magnets. PLoS ONE 12(4):e0175255

Kumar S, Loganathan VA, Gupta RB, Barnett MO (2011) An assessment of U(VI) removal from groundwater using biochar produced from hydrothermal carbonization. J Environ Manag 92:2504-2512

Kumar M, Gokulan R, Sujatha S et al (2021) Biodecolorization of reactive red 120 in batch and packed bed column using biochar derived from Ulva reticulata. Biomass Convers Biorefinery. https://doi.org/10.1007/s13399-020-01268-x

Lade H, Kadam A, Paul D, Govindwar S (2015) Biodegradation and detoxification of textile azo dyes by bacterial consortium under sequential microaerophilic/aerobic processes. EXCLI J 14:158-174

Lagergren S (1898) About the theory of so-called adsorption of soluble substances. Kungliga Svenska Vetenskapsakademiens Handlingar 24:1-39

Langmuir I (1916) Constitution and fundamental properties of solids and liquids. I. Solids. J Am Chem Soc 38(11):2221

Lee DJ, Cheng YL, Wong RJ, Wang XD (2018) Adsorption removal of natural organic matters in waters using biochar. Biores Technol 260:413-416

Li G, Zhu W, Zhang C, Zhang S, Liu L, Zhu L et al (2016) Effect of a magnetic field on the adsorptive removal of methylene blue onto wheat straw biochar. Bioresour Technol 206:16-22

Li X, Zhao C, Zhang M (2019) Biochar for Anionic Contaminants Removal from Water, Biochar from Biomass and Waste, pp. $143-160$

Liu P, Liu WJ, Jiang H, Chen JJ, Li WW, Yu HQ (2012) Modification of bio-char derived from fast pyrolysis of biomass and its application in removal of tetracycline from aqueous solution. Bioresour Technol 121:235-240

Lucchini P, Quilliam RS, DeLuca TH, Vamerali T, Jones DL (2013) Increased bioavailability of metals in two contrasting agricultural soils treated with waste wood derived biochar and ash. Environ Sci Pollut Res 1-11

Macek T, Mackova M (2011) Potential of Biosorption Technology, Microbial Biosorption of Metals, pp. 7-17

Malghani S, Gleixner G, Trumbore SE (2013) Chars produced by slow pyrolysis and hydrothermal carbonization vary in carbon 
sequestration potential and greenhouse gases emissions. Soil Biol Biochem 62:137-146

Mathur N, Bhatnagar P, Bakre P (2005) Assessing mutagenicity of textile dyes from pali (Rajasthan) using ames bioassay. Appl Ecol Environ Res 4(1):111-118

McKay G, Ho YS, Ng JCY (1999) Biosorption of copper from wastewaters: a review. Sep Purif Methods 28(1):87-125

McMullan G, Meehan C, Conneely A, Kirby N, Robinson T, Nigam P, Banat IM, Marchant R, Smyth WF (2001) Microbial decolourisation and degradation of textiles dyes. Appl Microbiol Biotechnol $56: 81-87$

Moghazy Reda M, Abdo Sayeda M (2018) The efficacy of microalgal biomass collected from high-rate algal pond for dyes biosorption and biofuel production. Res J Chem Environ 22(11):54-60

Mohan D, Pittman CU Jr, Bricka M, Smith F, Yancey B, Mohammad J, Steele PH, Alexandre-Franco MF, Gómez-Serrano V, Gong H (2007) Sorption of arsenic, cadmium, and lead by chars produced from fast pyrolysis of wood and bark during bio-oil production. J Colloid Interface Sci 310:57-73

Mohanty P, Nanda S, Pant KK et al (2013) Evaluation of the physiochemical development of biochars obtained from pyrolysis of wheat straw, timothy grass and pinewood: effects of heating rate. J Anal Appl Pyrolysis 104:485-493

Mukome FND, Zhang X, Silva LCR et al (2013) Use of chemical and physical characteristics to investigate trends in biochar feedstocks. J Agric Food Chem 61(9):2196-2204

Nartey OD, Zhao B (2014) Biochar preparation, characterization, and adsorptive capacity and its effect on bioavailability of contaminants: an overview. Adv Mater Sci Eng. https://doi.org/10.1155/ 2014/715398

National Geographic Society (2011) Dead zone I National Geographic Society. In: Explor. Your World Adventure Geogr

Neetha JN, Ujwal P, Sandesh K, Santhosh H, Girish K (2018) Aerobic biodegradation of Acid Blue-9 dye by Bacillus fermus Isolated from Annona reticulata. Environ Technol Innov 11:253-261

Novak JM (2019) Biochar from Biomass and Waste. II Future Biochar Research Directions. https://doi.org/10.1016/B978-0-12-8117293.00022-4

Ofomaja AE, Ho Y-S (2008) Effect of temperatures and pH on methyl violet biosorption by Mansonia wood sawdust. Bioresour Technol 99(13):5411-5417. https://doi.org/10.1016/j.biortech.2007. 11.018

Oliver DP, Pan YF, Anderson JS et al (2013) Sorption of pesticides by a mineral sand mining by-product, neutralised used acid (NUA). Sci Total Environ 442:255-262

Park J-H, Wang JJ, Meng Y, Wei Z, DeLaune RD, Seo D-C (2019) Adsorption/desorption behavior of cationic and anionic dyes by biochars prepared at normal and high pyrolysis temperatures. Colloids Surf, A 572:274-282. https://doi.org/10.1016/j.colsu rfa.2019.04.029

Pereira L, Alves M (2012) Dyes-Environmental Impact and Remediation. Environmental Protection Strategies for Sustainable Development, pp. 111-162

Praveen S, Bhagavathi Pushpa T, Gokulan R, Jegan J (2020) Evaluation of the adsorption capacity of Cocos Nucifera shell derived biochar for basic dyes sequestration from aqueous solution. Energy Sources, Part A Recovery, Util Environ Effects. https://doi.org/ 10.1080/15567036.2020.1800142

Premkumar Y, Vijayaraghavan K (2015) Biosorption potential of cocopeat in the removal of methylene blue from aqueous solutions. Sep Sci Technol 50:1439-1446

Priya AK, Gokulan R, Vijaya Kumar A, Praveen S (2020) Biodecolorization of remazol dyes using biochar derived from Ulva reticulata: isotherm, kinetics, desorption and thermodynamic studies. Desalination Water Treat 200:286-295. https://doi.org/10.5004/ dwt.2020.26098
Qiu Y, Zheng Z, Zhou Z, Sheng GD (2009) Effectiveness and mechanisms of dye adsorption on a straw-based biochar. Bioresour Technol 100:5348-5351

Rajapaksha AU, Chen SS, Tsang DCW et al (2016) Engineered/ designer biochar for contaminant removal/immobilization from soil and water: potential and implication of biochar modification. Chemosphere 148:276-291

Ravindiran G, Ganapathy GP, Josephraj J, Alagumalai A (2019a) A critical insight into biomass derived biosorbent for bioremediation of dyes. ChemistrySelect 4(34):9762-9775

Ravindiran G, Jeyaraju RM, Josephraj J, Alagumalai A (2019b) Comparative desorption studies on remediation of remazol dyes using biochar (Sorbent) derived from green marine seaweeds. ChemistrySelect 4(25):7437-7445

Redlich O, Peterson DL (1959) A useful adsorption isotherm. J Phys Chem 63:1024-1026

Rita K (2012) Textile dyeing industry an environmental hazard. Nat Sci 4(1):1-5

Robinson T, Mcmullan G, Marchant R, Nigam P (2001) Remediation of dyes in textile effluent: a critical review on current treatment technologies with a proposed alternative. Biores Technol 77:247-255

Rosales E, Meijide J, Pazos M, Sanromán MA (2017) Challenges and recent advances in biochar as low-cost biosorbent: from batch assays to continuous-flow systems. Bioresour Technol. https:// doi.org/10.1016/j.biortech.2017.06.084

Sadhasivam S, Savitha S, Swaminathan K (2007) Exploitation of Trichoder maharzianum mycelial waste for the removal of Rhodamine 6G from aqueous solution. J Environ Manage 85:155-161

Saha GC, Hoque MIU, Miah MAM, Holze R, Chowdhury DA, Khandaker S, Chowdhury S (2017) Biosorptive removal of lead from aqueous solutions onto Taro (Colocasiaesculenta (L.) Schott) as a low cost bioadsorbent: characterization, equilibria, kinetics and biosorption-mechanism studies. J Environ Chem Eng 5(3):2151-2162

Saleh ME, El-Refaey AA, Mahmoud AH (2016) Effectiveness of sunflower seed husk biochar for removing copper ions from wastewater: a comparative study. Soil \& Water Res 11:53-63

Salleh MAM, Mahmoud DK, Abdul Karim WAW, Idris A (2011) Cationic and anionic dye adsorption by agricultural solid wastes: a comprehensive review. Desalination 280:1-13

Sathishkumar M, Binupriya A, Vijayaraghavan K, Yun S (2007) Two and three-parameter isothermal modeling for liquid-phase sorption of Procion Blue H-B by inactive mycelial biomass of Panus fulvus. J Chem Technol Biotechnol 82:389-398

Schiewer S, Volesky B (1995) Modelling of proton-metal ion exchange in biosorption. Environ Sci Technol 29(12):3049-3058

Schwarzenbach RP, Egli T, Hofstetter TB et al (2010) Global water pollution and human health. Annu Rev Environ Resour. https:// doi.org/10.1146/annurev-environ-100809-125342

Shakoor MB, Ali S, Rizwan M, Abbas F, Bibi I, Riaz M, Khalil U, Niazi NK, Rinklebe J (2019) A review of biochar-based sorbents for separation of heavy metals from water. Int J Phytoremediation. https://doi.org/10.1080/15226514.2019.1647405

Shi L, Wei D, Ngo HH, Guo W, Du B, Wei Q (2015) Application of anaerobic granular sludge for competitive biosorption of methylene blue and $\mathrm{Pb}(\mathrm{II})$ : fluorescence and response surface methodology. Biores Technol 194:297-304

Shooto ND, Dikio CW, Wankasi D, Sikhwivhilu LM, Mtunzi FM, Dikio ED (2016) Novel PVA/MOF nanofibres: fabrication, evaluation and adsorption of lead ions from aqueous solution. Nanosc Res Lett 11(1):414. https://doi.org/10.1186/s11671-016-1631-2

Sivarajasekar N, Baskar R (2013) Adsorption of basic red 9 onto activated carbon derived from immature cotton seeds: isotherm studies and error analysis. Desalin Water Treat 52(40-42):7743-7765 
Stella Mary G, Sugumaran P, Niveditha S et al (2016) Production, characterization and evaluation of biochar from pod (Pisum sativum), leaf (Brassica oleracea) and peel (Citrus sinensis) wastes. Int J Recycl Org Waste Agricult 5:43-53. https://doi.org/10.1007/ s40093-016-0116-8

Streith J (2018) Regiotrirhena, Chemical and pharmaceutical industries and the Mulhouse Chemistry School. C R Chim 21(2):131-151

Suliman W, Harsh JB, Abu-Lail NI, Fortuna A-M, Dallmeyer I, GarciaPerez M (2016) Influence of feedstock source and pyrolysis temperature on biochar bulk and surface properties. Biomass Bioenergy 84:37-48. https://doi.org/10.1016/j.biombioe.2015.11.010

Sun K, Jin J, Keiluweit M, Kleber M, Wang Z, Pan Z et al (2012) Polar and aliphatic domains regulate sorption of phthalic acid esters (PAEs) to biochars. Bioresour Technol 118:120-127

Tareq R, Akter N, Azam MS (2019) Biochars and Biochar Composites, Biochar from Biomass and Waste, pp. 169-209

Thillainayagam BP, Saravanan P, Ravindiran G et al (2021) Continuous sorption of methylene blue dye from aqueous solution using effective microorganisms-based water hyacinth waste compost in a packed column. Biomass Convers Biorefinery. https://doi.org/ 10.1007/s13399-020-01208-9

Thines KR, Abdullah EC, Mubarak NM, Ruthiraan M (2017) Synthesis of magnetic biochar from agricultural waste biomass to enhancing route for waste water and polymer application: a review. Renew Sustain Energy Rev 67:257-276

Thompson KA, Shimabuku KK, Kearns JP, Knappe DRU, Summers RS, Cook SM (2016) Environmental comparison of biochar and activated carbon for tertiary wastewater treatment. Environ Sci Technol 50:11253-11262

Tong XJ, Li JY, Yuan JH, Xu RK (2011) Adsorption of Cu (II) by biochars generated from three crop straws. Chem Eng J 172:828-834

Uchimiya M, Lima IM, Thomas Klasson K, Chang S, Wartelle LH, Rodgers JE (2010) Immobilization of heavy metal ions (CuII, CdII, NiII, and PbII) by broiler litter-derived biochars in water and soil. J Agric Food Chem 58:5538-5544

Uddin MT, Rahman MA, Rukanuzzaman M et al (2017) A potential low cost adsorbent for the removal of cationic dyes from aqueous solutions. Appl Water Sci 7:2831-2842. https://doi.org/10.1007/ s13201-017-0542-4

Varshini JSC, Das N (2014) Relevant approach to assess the performance of biowaste materials for the recovery of Lanthanum (III) from aqueous medium. Res J Pharm, Biol Chem Sci 5(6):88-94

Vijayaraghavan K (2019) Recent advancements in biochar preparation, feedstocks, modification, characterization and future applications. Environ Technol Rev 8(1):47-64. https://doi.org/10.1080/ 21622515.2019.1631393

Vijayaraghavan K, Ashokkumar T (2019) Characterization and evaluation of reactive dye adsorption onto Biochar Derived from
Turbinaria conoides Biomass. Environ Prog Sustain Energy. https://doi.org/10.1002/ep.13143

Vijayaraghavan K, Yun YS (2008a) Bacterial biosorbents and biosorption. Biotechnol Adv 26(3):266-291

Vijayaraghavan K, Yun YS (2008b) Biosorption of C.I. Reactive black 5 from aqueous solution using acid treated biomass of brown seaweed Laminaria. Dyes Pigm 76(3):726-732

Wahab R et al (2017) Photocatalytic TMO-NMs adsorbent: temperature-time dependent Safranine degradation, sorption study validated under optimized effective equilibrium models parameter with standardized statistical analysis. Sci Rep 7:42509. https:// doi.org/10.1038/srep42509

Wang X, Gu X, Lin D, Dong F, Wan X (2007) Treatment of acid rose dye containing wastewater by ozonizing-biological aerated filter. Dyes Pigm 74(3):736-740

Wang B, Zhu Y, Bai Z, Luque R, Xuan J (2017) Functionalized chitosan biosorbents with ultra-high performance, mechanical strength and tunable selectivity for heavy metals in wastewater treatment. Chem Eng J 325:350-359

Wang Y, Qiu L, Zhu M et al (2019) Comparative evaluation of hydrothermal carbonization and low temperature pyrolysis of eucommia ulmoides oliver for the production of solid biofuel. Sci Rep 9:5535. https://doi.org/10.1038/s41598-019-38849-4

Wang X, Guo Z, Hu Z, Zhang J (2020) Recent advances in biochar application for water and wastewater treatment: a review. PeerJ 8:e9164. https://doi.org/10.7717/peerj.9164/fig-1

Waqas M, Asam Z, Rehan M, Anwar MN, Khattak RA, Ismail IMI, Tabatabaei M, Nizami AS (2020) Development of biomassderived biochar for agronomic and environmental remediation applications. Biomass Convers Biorefinery. https://doi.org/10. 1007/s13399-020-00936-2

Woolf D, Amonette J, Street-Perrott F et al (2010) Sustainable biochar to mitigate global climate change. Nat Commun 1:56. https://doi. org/10.1038/ncomms 1053

Xiao X, Chen B, Chen Z, Zhu L, Schnoor JL (2018) Insight into multiple and multilevel structures of biochars and their potential environmental applications: a critical review. Environ Sci Technol 52(9):5027-5047. https://doi.org/10.1021/acs.est.7b06487

Xin S, Zeng Z, Zhou X, Luo W, Shi X, Wang Q, Du Y (2017) Recyclable Saccharomyces cerevisiae loaded nanofibrous mats with sandwich structure constructing via bio-electrospraying for heavy metal removal. J Hazard Mater 324:365-372

Yagub MT, Sen TK, Afroze S, Ang HM (2014) Dye and its removal from aqueous solution by adsorption: a review. Adv Coll Interface Sci 209:172-184 